\title{
THE ECONOMIC IMPACT OF SOUTH AFRICA'S INTERNATIONAL AIRPORTS
}

\author{
ROSE LUKE* \\ JACKIE WALTERS \\ *rluke@uj.ac.za \\ Institute of Transport and Logistics Studies (Africa) \\ University of Johannesburg \\ South Africa
}

\begin{abstract}
Infrastructure is strongly linked to economic growth and plays a major role in providing greater mobility and choice, leading to an improvement in incomes and welfare. Transport infrastructure such as highways, bridges, ports, airports and railways is critical in achieving economic growth. If the supply of these facilities does not keep up with rising demand, the cost of moving goods will increase, and there will be a downward pressure on profits and growth. Airports play a critical role in generating employment within an economy, creating wealth, contributing to the tax base, stimulating tourism and contributing to world trade. While the latter two are less easily measured, it is possible to determine a base impact that an airport has on an economy by measuring the direct and indirect gross domestic product, employment and taxation impacts. This study quantifies these for the three main international airports in South Africa.
\end{abstract}

\section{INTRODUCTION}

The foundation of many countries' economies is often described as the nature and extent of government capital expenditure in that economy. 'The roads, water and sewer systems that make up the majority of public capital allow for lower transportation costs and greater concentrations of people and firms, promote agglomeration economies and provide access to broader, deeper markets' (Macdonald, 2008: 7). The provision of appropriate levels of infrastructure is generally accepted as having a positive effect on economic growth and development. While it is not possible to establish exact correlations between levels of infrastructure investment and the associated economic growth levels, sufficient evidence exists to suggest that appropriate levels of infrastructure and economic growth are directly and positively related (Canning \& Pedroni, 2004: 2; Frankel, 1998: 8; Willoughby, 2002: 3; Banerjee, Duflo \& Qian, 2009: 2; Snieska \& Simkunaite, 2009: 16).

Infrastructure plays two roles in any economy: first as an intermediate good which implies that it facilitates the mobility of labour, capital and other inputs to production thus improving productivity and reducing costs; it also increases information flows, opening new 
opportunities and reducing asymmetries and other market imperfections. Secondly, it plays a role as a final good, implying that the consumption of infrastructure services improves quality of life through 'access to power, clean water, telephones, and serviceable roads and mass transit all provid[ing] people with greater mobility and improved choice leading to an improvement in incomes and welfare' (Finlayson, 2008: 3).

The link between appropriate infrastructure provision and economic growth is commonly recognised in academic literature (Canning \& Pedroni, 2004: 2; Frankel, 1998: 8; Willoughby, 2002: 3; Banerjee, Duflo \& Qian, 2009: 2; Snieska \& Simkunaite, 2009: 16). 'Infrastructure investments have been proposed in the development literature as an influential factor of economic growth, working through at least two of the three classic drivers of economic growth: directly via capital accumulation and indirectly via total factor productivity gains. Infrastructure investments are hypothesized to facilitate private investments by lowering production costs and opening new markets, thereby creating new production, trade and profit opportunities' (Fedderke and Bogetić, 2006: 2).

Moreover, the linkage is firmly entrenched in the political arena as well as the private sector. Senator B Nelson (2009) stated in a recent address that 'Modernizing our infrastructure will help keep America competitive, create thousands of jobs while stimulating the economy, and improve the lives of all citizens'. This type of recognition of the importance of infrastructure to the national economy and its growth is now also commonly recognised in South Africa (Gordhan, 2009; Manuel, 2009).

The 'availability of appropriate economic and social infrastructure represents a major platform for promoting economic growth' (Kirsten, 2006: 1). The 'need to address backlogs, and to upgrade and expand key social and economic infrastructure are cornerstones of government's policy, strategy and programmes to promote sustainable economic growth and to achieve a better life for all.' This has recently been reiterated in the Accelerated and Shared Growth Initiative for South Africa (AsgiSA) (Kirsten, 2006: 1).

The link between infrastructure investment and economic growth is widely acknowledged, where infrastructure can be inclusive of transport, telecommunications, electricity/power, transport, water and sanitation networks. The transport infrastructure referred to is inclusive of highways, bridges, ports, airports and railways.

The provision of this infrastructure is critical in its contribution to a country achieving appropriate levels of economic growth and yet 'ports, rail/truck connections and airports are at capacity all over the globe. If the supply of roads, rail, ports and intermodal facilities do not keep up with rising demand, congestion, air pollution and the cost of moving goods will increase, and there will be a downward pressure on profits and growth' (Accenture, 2003: 3). 
Airports specifically are considered critical to the economy of any region. Aside from supporting trade and tourism, as well as providing critical global linkages, airports are generally accepted as significant contributors to employment, the fiscus and the gross domestic product (GDP) of a region (Anon, n.d.; ACl, 2002: 1; ACl-Europe, 2004; IATA Economics, 2007: 1; Melbourne Airport, 2003; Trethaway, 2001; Vickerman, 2007). An Air Transport Action Group (ATAG) report (2005: 2) estimates that the global economic impact (direct, indirect, induced and catalytic) of air transport totals approximately $8 \%$ of the world's GDP. Employment (again direct, indirect, induced and catalytic impacts) is estimated at a global total of 29 million, 5 million of which are employed directly by airports, airlines and the aerospace industry. It is widely acknowledged that the air transport industry is a significant contributor to the total global economic activity and these figures provide some indication of its magnitude and importance. 'Aviation provides the only worldwide transportation network, which makes it essential for global business and tourism. It plays a vital role in facilitating economic growth, particularly in developing countries (ATAG, 2005: 2).

The economic impact of a particular airport would however be significantly undervalued if considered in global terms only. Any airport has a considerable impact on the region within which it is situated, including on the employment within the region, the tax base and the GDP. Aviation has an influence on tourism, as well as trade. It also has an impact on where companies invest and is particularly important for key growth areas. Users depend on airports for network connectivity while aviation in general supports business efficiency. Airport development however could have 'wider GDP benefits ... and reduce congestion costs' (Oxford Economic Forecasting, 2006). Air transport also facilitates world trade and boosts productivity across the global economy. Air transport improves the efficiency of the supply chain and is widely regarded as an enabler of investment both into and out of countries and regions. It also acts as a spur to innovation and provides consumer welfare benefits to individuals using air transport (ATAG, 2005: 9). Airports globally create thousands of jobs, generate considerable income through sales and income and generally contribute significantly to the total economic activity of its surrounding region through wages, income generated by tourism and business spending, airport activities and operations and airportrelated businesses (Washington State Department of Transport, 2001: 1).

The typical impacts of an airport can therefore be broadly listed as:

- Airports generate employment.

- Airports create wealth.

- Airports stimulate tourism.

- Airports have wider benefits to economy as a whole.

- Airports are major contributors to the tax base.

- Airports contribute to world trade (ATAG, 2005; Price, 2006).

To determine the impact an airport has on an economy, it would be necessary to identify and quantify each of these impacts. While some of the direct impacts such as GDP, employment 
and taxation effects are readily quantifiable, it is however less easy to quantify impacts such as the contribution to world trade. To determine a minimum impact of an airport it is therefore necessary to identify the readily quantifiable effects, while recognising that the airport potentially has a greater impact on the economy as a whole.

The objective of this research was to determine the minimum economic impact of South Africa's three main international airports (OR Tambo International Airport in Johannesburg, Gauteng; Durban International Airport in KwaZulu-Natal'; and Cape Town International Airport, Western Cape) on their provincial economies and South Africa as a whole to inform decision-makers on the relative impact of investments in such infrastructure. To this end, the research focused on measuring only the employment, tax revenue, personal income and GDP's impacts of the three airports on their respective provincial economies and South Africa as a whole.

\section{RESEARCH STRATEGY}

\section{Business and domestic passenger surveys}

The point of departure for this research was to determine the levels of activity at South Africa's three major international airports, OR Tambo International Airport (ORTIA) (in Johannesburg), Cape Town International Airport (CTIA) and Durban International Airport (DIA). Data was collected from a number of sources. These included the Airports Company South Africa Ltd (ACSA), which is responsible for the management of the nine state-owned airports, the Airports Council International $(\mathrm{ACl})$, Statistics South Africa (Stats SA), the Department of Transport (DoT), South African Revenue Services (SARS), Department of Environmental Affairs and Tourism (DEAT) and South African Tourism (SAT). Data from these sources differed significantly in terms of detail and reporting formats and therefore only trends in the data were used.

The second part of the study required the collection of various data via a number of survey processes conducted in 2007/2008. An airport typically affects the local economy on two levels, first through the businesses that are dependent on the existence of the airport and secondly, through the domestic, regional and international passengers who use the airport.

The businesses at the airports as well as the passengers using the airports have a direct impact on the local economy. Businesses at the airports employ workers. These employees and businesses, in turn, spend money on-airport as well as in the local (off-airport) economy.

\footnotetext{
1 Since writing this article, the Durban International Airport has been decommissioned and a new airport, the King Shaka International Airport, 30 kilometers north of Durban, has been commissioned.
} 
Business information was collected via a survey distributed in 2007, on 2006 data, to all businesses based at the three airports, based on the ACSA tenants' register, verified for completeness during the research project, using a survey instrument designed to identify the direct impacts of the businesses. Several steps were taken to ensure validity. In particular, the questionnaire was sent to a project panel for perusal and comments. As the purpose of the study was to ascertain a minimum economic impact, only the businesses located at the airports were surveyed. Many businesses that trade in one way or another with the airport are based off-airport, in the areas surrounding the airport. These were not surveyed due to funding constraints.

The business surveys were categorised into the following groups: airlines, fixed-base operators or tenants, ground transport companies, concessionaires, forwarding and clearing agents, air freight companies, car rental companies and government agencies, and were designed to be unique to each of these categories. The survey instrument measured aspects such as employment, wages, revenue and off-airport expenditure. Note that business expenses at the airport were recorded as the revenue of the businesses at which such expenses were recorded. This avoided the double-counting of expenses and revenues at the airport.

The total population of businesses based at ORTIA, CTIA and DIA was surveyed. A total of 291 surveys were returned comprising a response rate of $41 \%, 55 \%$ and $69 \%$ from ORTIA, CTIA and DIA respectively. The responses were then extrapolated per business category per airport to estimate population totals. In order to verify the accuracy of the extrapolation process, the actual annual turnovers of the businesses at the airport (as reported to ACSA) were compared to the estimated turnover following the extrapolation process.

Domestic, regional and international passengers using the airports also spend money at the airport (on-airport), as well as in the local economy (off-airport). A sample of passengers was therefore taken at each airport to obtain the off-airport (but within the province) spending characteristics. This passenger expenditure is primarily on accommodation, car rental, entertainment and other purchases. The expenditure by passengers at the airport was captured in the revenue of the companies based at the airport and therefore not recaptured in the passenger survey.

The information obtained in this survey was used to estimate the total passenger spending per airport. To estimate population totals for the year, the sample needed to be random and representative of passenger movements for the entire year. Departing passengers were interviewed. Over 1000 interviews were conducted in 2008 and the survey patterns and results compared to the SAT data to ensure validity. Data was normalised with 2006 SAT data to ensure compatible annualised results. The data showed homogenous patterns in terms of the aspects under review, such as spending patterns. The data triangulation 
process also showed high levels of correlation between the data sets, thus indicating that the data were sufficiently representative.

The objective of the domestic passenger survey was to obtain the expenditures of visiting passengers within the respective provinces. It was necessary to exclude the provincial residents from the sample as passengers residing in the province would naturally incur expenses in the province that would not necessarily be airport-related. To incorporate this a 60:40 split was assumed, i.e. $60 \%$ of the departing passengers at the airport reside outside the relevant province. ${ }^{2}$ This percentage was used to adjust the population size, i.e. the number of departing passengers who reside in other provinces.

SAT conducts regular passenger surveys targeting departing foreign tourists at ORTIA and CTIA. The samples are representative of foreign tourists using the airports in terms of country of origin, day and time of departure and the month of departure. For the purposes of this study SAT information on length of stay and spending patterns for these two airports was used. The surveys at ORTIA and CTIA therefore excluded foreign visitors.

The SAT surveys do not however cover DIA and it was therefore necessary to conduct a survey at the airport to obtain the required information. International passengers departing directly from DIA to foreign destinations constituted only $0.8 \%$ of the total number of departing international passengers from all three airports combined in 2007 (ACSA departing passenger information). However a significant portion of passengers departing on domestic flights are foreign visitors leaving for a connecting international flight via ORTIA or CTIA. Therefore, the sample at DIA was designed to include foreign visitors. Statistical representativeness was achieved by selecting passengers on a random basis and on every day of the week during the survey period in 2008. The sample was also proportionally representative of the domestic destination patterns.

\section{Population estimation methodology}

The international passenger information required for ORTIA and CTIA was obtained from SAT while the sample information for DIA was obtained during the survey process and used to estimate population averages. The information for all airports was stratified according to the purpose of visit, i.e. holiday, business, visiting friends and relatives (VFR), and other.

ACSA records the arriving and departing passengers at each of the airports. These figures include local South African residents, South African residents living in other provinces and foreign visitors. To evaluate the impact of each airport on its local province, passengers

2 This split was assumed at survey stage, based on a previous study and was verified in the data analysis phase following the surveys at ORTIA and CTIA. 
living in that specific province were excluded from the analysis. Foreign visitors departing on a domestic flight at ORTIA and CTIA were also excluded to avoid double counting. Foreign visitors departing from DIA were included in the international survey as only a few international departing flights take place directly from DIA. To estimate this split a count was done as shown in Table I.

Table I: Domestic passenger split (2008)

\begin{tabular}{|l|c|c|c|}
\hline & ORTIA & CTIA & DIA \\
\hline Departing passengers (ACSA) & 5524121 & 3451841 & 2385268 \\
\hline Local SA residents & $43.5 \%$ & $40.3 \%$ & $48.0 \%$ \\
\hline Other SA province residents & $34.5 \%$ & $52.5 \%$ & $39.5 \%$ \\
\hline Foreign visitors & $22.0 \%$ & $7.2 \%$ & $12.5 \%$ \\
\hline \multicolumn{1}{|c|}{ TOTAL (relevant domestic dep.) } & $\mathbf{1 9 0 5 8 2 2}$ & $\mathbf{1 8 1 2 \mathbf { 2 1 7 }}$ & $\mathbf{9 4 2} \mathbf{1 8 1}$ \\
\hline
\end{tabular}

Source: Compiled from information collected for the study

These figures (relevant domestic departures) were used to extrapolate the sample information to the population. The average length of stay per passenger by purpose of visit at each airport was calculated from the sample data. The average expenditure per day by each domestic passenger was also calculated. These figures were used to estimate total annual off-airport expenditure by purpose of visit for domestic passengers.

\section{Determination of the multiplier effects}

Business and passenger off-airport activities have an indirect and induced impact on local economies as off-airport spending results in sustainable employment and business activities in the local economies. The indirect economic impacts, with respect to employment, revenue, personal income and taxes, are calculated by using the appropriate economic multipliers. The indirect economic impacts, together with the direct economic impacts, provide an indication of the total economic impact of the airports on the respective local economies.

An 'input-output model can be used to provide a set of economic multipliers with which to trace the effects of changes in demand on economic activity in the region'/country (Schaffer, 2010: 5.1). Multipliers 'translate the consequences of change in one variable upon others, taking account of sometimes complicated and roundabout linkages' (Krumme, 2000). These effects are briefly defined in Table II. 
Table II: Different multiplier effects

\begin{tabular}{|l|l|}
\hline Multiplier & Description \\
\hline $\begin{array}{l}\text { Round zero - this } \\
\text { is the 'insertion' } \\
\text { or direct effect }\end{array}$ & $\begin{array}{l}\text { Transaction or flow table } \\
\text { Table of purchase and sales transactions between 'industries' within a (regional) system }\end{array}$ \\
\hline 1st round effect & $\begin{array}{l}\text { Table of direct (input) coefficients } \\
\text { Refers to direct production as a result of backward linkages to the particular business }\end{array}$ \\
\hline $\begin{array}{l}\text { Leontief inverse matrix/table } \\
\text { Indirect effect }\end{array}$ & $\begin{array}{l}\text { Table of Direct and Indirect Coefficients: measuring direct and indirect (industry) } \\
\text { effects } \\
\text { Table of Direct, Indirect and Induced Coefficients: 'Induced' effects are the result } \\
\text { of extending the tracing of indirect effects 'through' households, i.e. taking the } \\
\text { expenditures } \\
\text { Refers to the indirect effect as a result of forward and backward linkages in all other } \\
\text { sectors of the economy. These production activities are created because of the } \\
\text { purchasing of goods and services by businesses at the airports or businesses located } \\
\text { physically away from the airports, but whose activities involve the use of the airports, } \\
\text { in the respective local economies (the off-airport expenditure) }\end{array}$ \\
\hline Induced effect & $\begin{array}{l}\text { Refers to the indirect effect on production in the economy as a whole as a result of } \\
\text { increased household consumption expenditure. The income received by directly } \\
\text { employed employees is spent in the respective local economies, thus creating } \\
\text { production activities for other local residents }\end{array}$ \\
\hline
\end{tabular}

Direct annual revenues of businesses operating on-airport were estimated from the survey results. Production in these categories is dependent on an activity at the airports. Indirect production refers to production opportunities that are generated by related and spill-over off-airport activities.

There are a number of methods that can be employed for calculating the indirect multiplier effects. In this analysis, homogenous spending patterns were found and accurate annual revenues/final demand figures were available (Harris, 2003; Paris on Chaing, 2005) and multipliers could thus be applied directly. The Industrial Development Corporation of South Africa (IDC) multipliers were used.

Figure 1 depicts the approach taken to the multiplier effects, for the purposes of the study. 


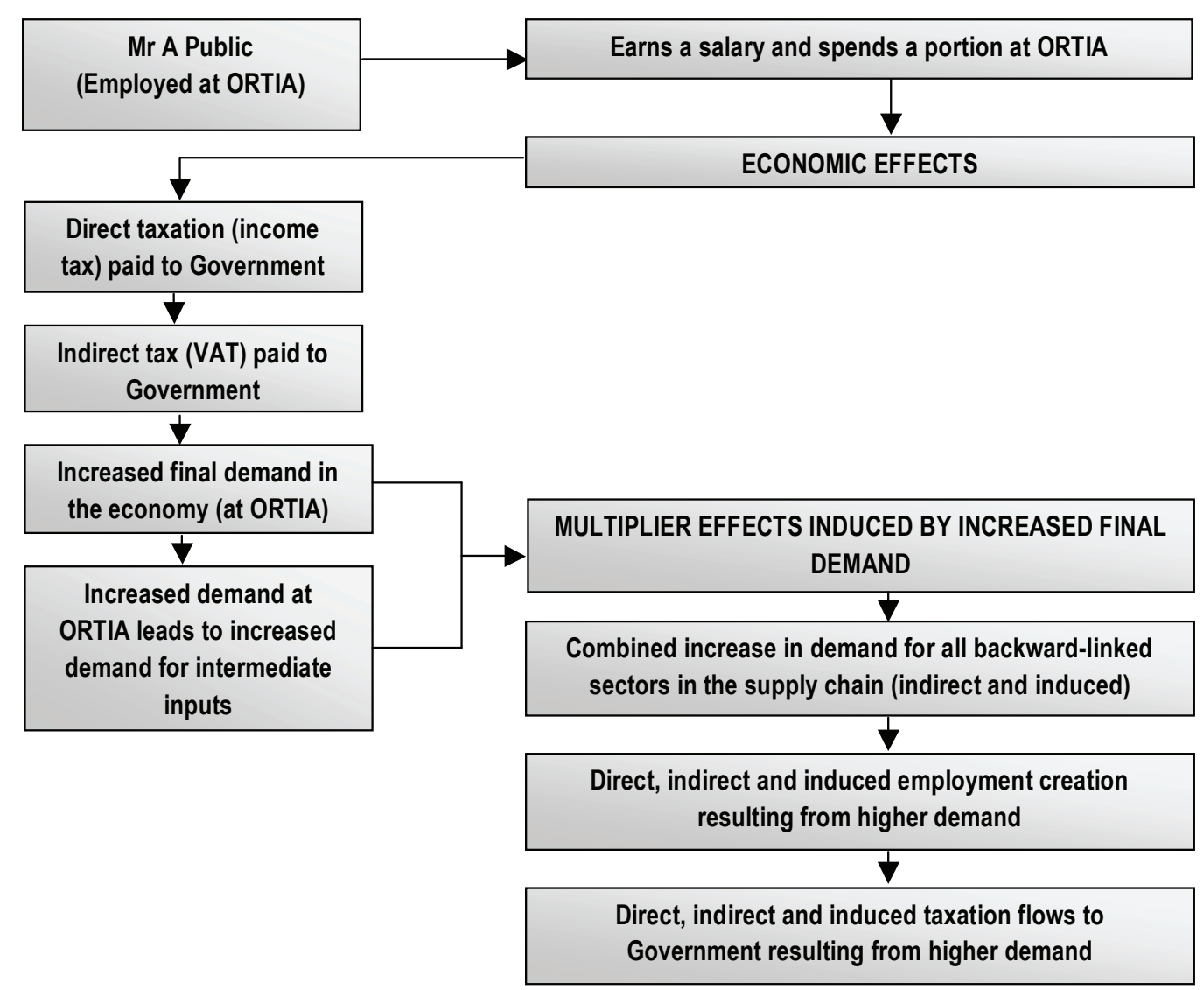

Figure 1: Example of the economic multiplier effect

(Source: Compiled for the purposes of the study)

\section{GDP and personal income effects}

The direct and indirect GDP and personal income effects of the three international airports (ORTIA, CTIA and DIA) were calculated based on the determination of the GDP and personal income effect 1) per airport; 2) per local economy; and 3) the combined effect of the three airports on South Africa. To avoid any possibility of double counting, the off-airport expenditure determined during the survey process was assumed to have been accounted for via the GDP multipliers.

To determine the GDP (production) effects of the three airports, the functional activities represented at each airport were grouped into specific input/output (I/O) sectors. Airlines, ground transport, forwarding and clearing, air freight and car rental companies were grouped together as transport storage and communication. Fixed-based operators were classified as trade and accommodation. Concessionaires and airport and air traffic management were listed as business services and government services were classified as 'other services'.

To determine the indirect GDP-multiplier effects for each airport, the direct on-airport annual revenues of business operating totals per $\mathrm{I} / \mathrm{O}$ sector and per airport were multiplied by the IDC GDP-multiplier ratios to get indirect GDP effects per I/O sector and per airport. 
The second contribution to the creation of production opportunities in the local economy is through off-airport passenger spending. International and domestic passengers generally spend a number of days in the local provinces (Gauteng [ORTIA], Western Cape [CTIA] and KwaZulu-Natal [DIA]). Passengers arrive and depart for a variety of reasons, mostly for business, holiday, transit or study. Each of these categories is associated with an average number of days that passengers stay in each local area. To determine the GDP-multiplier effects generated by passenger spending, the same multipliers were used.

There are therefore two types of GDP effects. First, the direct, indirect and induced GDP effects that result from actual on-airport production or businesses operating at each airport. Secondly, the direct, indirect and induced GDP effects of final demand passenger spending (international and domestic) are determined.

\section{Employment effects}

To determine the employment impacts of the three airports the functional activities at the airports were grouped into specific I/O sectors. The impact study considers only direct on-airport employment within all of the functional activities and the indirect employment opportunities generated by the various employment multiplier effects. Direct employment was estimated from the survey results. Indirect employment refers to employment opportunities that are generated by related and spill-over off-airport activities.

Note that the sets of employment multipliers for the transport, storage and communication sector, the trade and accommodation sector and the manufacturing sectors are averaged multipliers.

Two employment impacts were calculated. First, the direct and indirect employment impacts that result from actual on-airport employment at the three airports and secondly, the employment impacts of passenger spending (international and domestic passengers) at the airports.

\section{Tax revenue impacts}

The air transport industry in South Africa pays tax to the local, provincial and national governments. The businesses operating directly and indirectly on and off the three airports generate revenue on which various direct and indirect taxes are levied. Direct taxes are levied on profits made by these businesses (company tax) as well as salaries and wages paid to employees (personal income tax). Indirect taxes (such as value added tax) are levied on almost all products and services sold or delivered directly or indirectly at the three airports.

The IDC's 1) personal income tax multipliers; 2) company tax multipliers; and 3) indirect tax multipliers per selected $\mathrm{I} / \mathrm{O}$ sector were used to calculate the indirect taxation impacts per category of taxation. 
In addition, it is necessary to determine the impact of government indirect tax revenue that results from the linkage effects of business activities at the airports. To calculate this impact the total GDP impact of businesses and the GDP impact of passenger spending (grouped in the selected I/O sector) per airport are multiplied by the various indirect tax multipliers. Indirect tax multipliers for the transport, storage and communication sector, the trade and accommodation sector and the manufacturing sector are also average multipliers.

The economic impacts of the three airports were based on the impacts that these airports had on their respective provinces. Evidently these impacts extend beyond provincial borders, for example an international tourist entering the country through ORTIA on the way to a holiday in the Kruger National Park located in Mpumalanga. This type of impact was not reported as the focus of the study was on the impact of the airport on the provincial economies of each airport. The combined impact of the three airports is therefore a reflection of the impacts on the three provinces combined, and must therefore be regarded as a minimum measure of the impact on the South African economy.

\section{DISCUSSION}

As outlined above, airports generate significant effects on any economy and these can be measured in terms of GDP, personal income effects, employment impacts and/or tax revenue impacts.

\section{GDP-multiplier effects}

The combined GDP impact from business revenue is measured as the initial impact, the first round impact, the indirect effect and the induced effect. From a base of R39 108m (total annual business revenues at the three airports) the total additional effect is a further R85 $671 \mathrm{~m}$, indicating a multiplier effect of 2.19 .

The second contributor to the creation of production opportunities in the local economy is through off-airport passenger spending (national and international). For purposes of correlation with the sector classification contained in the $1 / O$ tables, the annual passenger spending by item and by airport was again classified accordingly, for example, hotels and food were reclassified into the trade and accommodation category.

The GDP effects of off-airport passenger spending were calculated by multiplying actual spend by the IDC's GDP multipliers to determine initial impacts, first round impacts, indirect effects and induced effects. These are then added to produce a total per I/O sector per airport for both domestic and international passengers. The results of this indicated a combined direct and indirect GDP-multiplier effect of the three airports (based on the direct off-airport passenger spending), from a base of R17 820m (domestic spending) plus 
R28 $014 m$ (international spending), a total R44 834m to a further R103 285m, with a multiplier of 2.30 .

In summary, ACSA's three international airports have an important direct and indirect production-creation impact in the South African economy. The combined GDP impact of ORTIA, CTIA and DIA, based on businesses operating on-airport and total domestic and international passenger spending off-airport, in the relevant economies, is summarised in Table III below.

Table III: Total combined GDP impacts of ( $\left.\mathrm{R}^{\prime} \mathrm{m}\right)$

\begin{tabular}{|l|c|c|c|c|}
\hline I/O sector & ORTIA & CTIA & DIA & Total (R'm) \\
\hline $\begin{array}{l}\text { Transport, storage and } \\
\text { communication }\end{array}$ & 55657.2 & 28622.3 & 8075.9 & 92355.4 \\
\hline Trade and accommodation & 20886.5 & 19265.1 & 8640.2 & 48791.8 \\
\hline Business services & 2784.1 & 1538.4 & 29.1 & 4351.6 \\
\hline Manufacturing & 19109.1 & 9350.7 & 5099.7 & 33559.5 \\
\hline Other & 5972.7 & 2610.7 & 1315.0 & 9898.4 \\
\hline TOTAL & $\mathbf{1 0 4 4 0 9 . 6}$ & $\mathbf{6 1 3 8 7 . 4}$ & $\mathbf{2 3 1 5 9 . 8}$ & $\mathbf{1 8 8 9 5 6 . 8}$ \\
\hline
\end{tabular}

The combined direct and indirect GDP-multiplier effect of the three airports (based on the direct off-airport passenger spending) is sizeable: from R17 $820 \mathrm{~m}$ (domestic spending) plus R28 014m (international spending), a total R44 834m to R188 956.8m, with a total multiplier effect of 4.21 .

\section{Employment impacts}

To determine the employment impacts of the three airports, only the direct on-airport employment and the indirect employment opportunities generated by the various indirect employment multiplier effects were considered.

The analysis of the employment impacts is divided into two parts. In the first, the direct and indirect employment impacts that result from actual on-airport employment at the airports are determined. The direct on-airport employment totals per airport are 20742 for ORTIA, 11115 for CTIA and 1861 for DIA (obtained in the survey process). The direct on-airport employment totals per $1 / O$ sector and per airport are multiplied by the various multipliers. The total employment impact is the total of the direct and indirect effects and totals 261403 employment opportunities for all three airports.

In the second part, the employment impacts of passenger spending (international and domestic passengers) at the airports are calculated. International and domestic passengers 
spend a number of days in the associated provinces (Gauteng, Western Cape and KwaZuluNatal). The employment impacts generated by passenger spending were calculated by applying the various employment multipliers to the GDP impacts of international and domestic passenger spending. The results show a further 134533 employment opportunities. This multiplier effect is smaller than the indirect on-airport employment impact, but is still an important creator of employment opportunities.

In summary, the three international airports have a considerable direct and indirect employment creation impact in the South African economy as is illustrated in Table IV.

Table IV: Overall combined employment impact of ORTIA, CTIA and DIA

\begin{tabular}{|l|c|c|c|c|}
\hline I/O sector & ORTIA & CTIA & DIA & Total \\
\hline $\begin{array}{l}\text { Transport, storage and } \\
\text { communication }\end{array}$ & 45539 & 20003 & 6428 & 71970 \\
\hline Trade and accommodation & 100493 & 33961 & 14930 & 149384 \\
\hline Manufacturing & 24045 & 11764 & 6418 & 42227 \\
\hline Business services & 23682 & 60560 & 4692 & 88934 \\
\hline Other services & 35516 & 5452 & 2453 & 43421 \\
\hline TOTAL & $\mathbf{2 2 9} \mathbf{2 7 5}$ & $\mathbf{1 3 1 7 4 0}$ & $\mathbf{3 4 9 2 1}$ & $\mathbf{3 9 5} 936$ \\
\hline
\end{tabular}

The combined direct and indirect employment effect of the three airports is quite substantial, from 33718 (direct employment) to 362217 (indirect), i.e. for every direct employment opportunity at the airports, linked to the business and passenger spending at such airports, 10.7 other jobs are created in the economy of the respective provinces.

\section{Tax revenue impacts of ORTIA, CTIA and DIA \\ Income tax impacts}

The total annual salaries paid to on-airport employed individuals at each airport were obtained via the survey process. To determine the direct taxation impact of employment at each airport, the direct Pay As You Earn (PAYE) component of the annual salaries paid to employees was calculated. To do this, 1) an 80/20 percentage split between low-to-middle and high-income earners was assumed, and 2) a 25\% average tax rate for the low-to-middle income group and a 40\% average tax rate for the high-income group are applied.

The second dimension of the taxation impact of the employment of individuals is the indirect taxation effects that flow from on-airport PAYE. To calculate these, the various income tax multipliers per specified I/O sector are applied. 
The third dimension of the income tax effects is the income tax arising from the employment created by passenger (domestic and international) spending. The total employment impact of domestic and international passenger spending for each airport was used in this calculation. This total is multiplied by an average income of R120 000 and finally by the tax/ income ratio of $25 \%$.

\section{Corporate taxation impacts}

On-airport revenue was taken from the survey results and extrapolated across all businesses. The direct company tax was calculated using the same tax rate per I/O sector. Secondly, the indirect company tax effects based on the direct company tax per $1 / O$ sector were calculated. The various company tax multipliers per $\mathrm{I} / \mathrm{O}$ sector are multiplied with the direct taxes per I/O sector.

Passenger spending not only creates indirect income tax impacts but also indirect company tax impacts as companies selling products and services to these passengers must pay company taxes. To calculate this, the indirect GDP passenger impacts are multiplied by the company tax multipliers. The result is the indirect company tax impacts arising from domestic passenger spending.

The total direct and indirect company tax impacts thus comprise direct company tax, indirect company tax effects and passenger spending indirect company tax effects.

\section{Indirect taxation impacts}

The first category of indirect taxes is the net Value Added Tax (VAT) position of businesses operating at each airport. The revenue and off-airport expenditure figures of the businesses exclude VAT. To calculate the net VAT totals, output VAT on revenue totals and input VAT figures on expenditure totals is calculated. To determine the net VAT position, the input VAT is subtracted from the output VAT.

The next category is the indirect tax multiplier effects of the GDP impacts of on-airport firms and of passenger spending. The GDP impacts of on-airport business activities per I/O sector are added to those for the GDP impacts of passenger spending per $1 / O$ sector. The combined totals are then multiplied by the various multipliers per $\mathrm{I} / \mathrm{O}$ sector. The indirect tax impacts are then collated to determine the total.

\section{Total taxation impacts}

The total estimated taxation impacts of the three airports are listed in Table V. 
Table V: Total combined tax impacts of ORTIA, CTIA and DIA (R'm)

\begin{tabular}{|l|c|c|c|c|}
\hline Tax category & ORTIA & CTIA & DIA & Total \\
\hline Personal income tax & 2282.23 & 1583.84 & 689.89 & 4555.96 \\
\hline Company tax & 1377.53 & 833.63 & 304.69 & 2515.85 \\
\hline Indirect tax & 4178.58 & 2310.36 & 537.60 & 7026.54 \\
\hline TOTAL & $\mathbf{7 8 3 8 . 3 4}$ & $\mathbf{4 7 2 7 . 8 3}$ & $\mathbf{1 5 3 2 . 1 8}$ & $\mathbf{1 4 0 9 8 . 3 5}$ \\
\hline
\end{tabular}

The combined taxation impact of the three imports (R14.1b) is important (it represents approximately $2.5 \%$ of the total tax revenue of the state for the 2007-2008 fiscal year).

\section{CONCLUSION}

Airport infrastructure requires major investment, usually and primarily from the public sector. To acquire this type of funding, the relevant authorities would be required to show that sufficient justification exists in terms of social and economic benefits to the economy. The literature shows that airports contribute to economic growth and development, specifically in terms of generating employment, creating wealth, stimulating tourism, contributing to the tax base, contributing to world trade and generally creating wider benefits to the economy as a whole. While the stimulation of tourism and the contribution to world trade are not easily determined, input/output models can be used to calculate the direct, indirect and induced effect on the GDP, employment and taxation.

The study shows that the three main international airports in South Africa, OR Tambo International Airport, Durban International Airport and Cape Town International Airport, have major impacts on their provincial economies and resultantly on the South African economy as a whole. The combined direct and indirect GDP-multiplier effect of the three airports is sizeable, from R44 $834 \mathrm{~m}$ to R188 $956.8 \mathrm{~m}$, with a multiplier effect of 4.21 . The employment effects are even greater, indicating that for every direct employment opportunity at the airports a further 10.7 other jobs are created in the relevant provincial economy. Finally, the study shows that the airports had a combined taxation impact of a considerable $2.5 \%$ of the total fiscus for the 2007-2008 financial year.

These figures show that these airports have and, with appropriate planning, protection, investment and support, will continue to have major benefits for the South African economy in terms of wealth creation, employment creation and contribution to the fiscus - a significant annual return on investment to South Africa and its communities. 


\section{REFERENCES}

Accenture. 2003. Developing infrastructure to facilitate economic growth. Available from: http://www.accenture.com/NR/rdonlyres/93115A0E-60F5-4174-A927-A67B377ADBA4/0/ developing_infrastructure.pdf (accessed 11 November 2010).

ACl-Europe. 2004. The economic and social impact of airports in Europe. Available from: http://www.lydd-airport.co.uk/documents/The_social_and_economic_impact_of_airports_ in_Europe.pdf (accessed 22 November 2009).

Airports Council International (ACl). 2002. The economic impact of U.S. airports. Available from: http://www.waitakere.govt.nz/abtcit/whenuapai/pdf/usecoimpact.pdf (accessed 6 December 2009).

Anon. n.d. The importance of airport infrastructure to the economic development of Beaufort County. Available from: http://www.chhia.org/index.php?option=com_docman\&task=doc_ download\&gid=24\&ltemid=27 (accessed 7 December 2009).

ATAG. 2005. The economic and social benefits of transport. Available from: http://www. iata.org/pressroom/Documents/atag_economic_social_benefits_2008.pdf (accessed 12 December 2009).

Banerjee, A., Duflo, E. and Qian, N. 2009. On the road: Access to transportation infrastructure and economic growth in China. Preliminary version. Available from http://igov.berkeley.edu/ content/road-access-transportation-infrastructure-and-economic-growth-china (accessed 20 November 2009).

Canning, D. and Pedroni, P. 2004. The effect of infrastructure on long run economic growth. Mimeo. Harvard University.

Fedderke, J. W. and Bogetic, Z. 2006. Infrastructure and growth in South Africa: direct and indirect productivity impacts of 19 infrastructure measures. Policy Research Working Paper Series 3989, The World Bank.

Finlayson, B. 2008. Infrastructure for economic growth and development. Available from: http://www.adbi.org/files/2008.11.cpp.session.1.finlayson.infrastructure.economic.growth. dev.pdf (accessed 17 January 2010).

Frankel, J. A. 1998. Why economies grow the way they do. Canadian Business Economics 6, 3-13. 
Gordhan, P. 2009. Introductory speech. Available from: http://www.treasury.gov.za/comm_ media/speeches/2009/2009090102.pdf (accessed 11 November 2009).

Harris, T. 2003. Input-output model basics. Available from http://srdc.msstate.edu/trainings/ presentations_archive/\#03 (accessed 3 February 2010).

IATA Economics. 2007. Economic benefits from air transport in Bolivia. Available from http:// clacsec.lima.icao.int/IATA-Estudio/bolivia_eng.pdf (accessed 17 December 2009).

Kirsten, M. (ed). 2006. The DBSA infrastructure barometer 2006. Midrand: Development Bank of Southern Africa.

Krumme, G. 2000. Analysis of interdependence structures: Input-output. Available from http://faculty.washington.edu/krumme/207/inputoutput.html (accessed 3 December 2009).

Macdonald, R. 2008. An examination of public capital's role in production. Economic Analysis Research Paper Series. Catalogue no. 11F0027M - No.050.

Manuel, T. A. 2009. Budget speech. Available from: http://www.treasury.gov.za/documents/ national\%20budget/2009/speech/speech.pdf (accessed 11 November 2009).

Melbourne Airport. 2003. Melbourne Airport economic impact study. Malvern. Sinclair Knight Merz Pty Limited. Available from: http://www.melbourneairport.com.au/Media/ docs/EISFinalPublicVersion-9c4633db-9982-4cb7-8ced-f43cd315630f-0.pdf (accessed 7 December 2009).

Nelson, B. 2009. Importance of infrastructure. Available from: http://www.masoncontractors. org/newsandevents/masonryheadlines/headline.php?id=20090204145506 (accessed 11 Jan 2010).

Oxford Economic Forecasting. 2006. The economic contribution of the aviation industry in the UK. Available from http://www.oef.com/Free/pdfs/Aviation2006Final.pdf (accessed 21 January 2010).

Paris, T. B. 2005. Notes on Alpha C. Chiang. Fundamental methods of mathematical economics. McGraw Hill (4th edition). Available from: http://www.tbparis.com/Econ230/ Chiang-\%2520PPT\%2520Lectures/Notes-Chapter\%25205-Part\%25202-IO\%2520Analysis. ppt (accessed 3 February 2010).

Price, L. 2006. The role of airports as economic development drivers. Presented at Towards Sustainable Airport Development. 
Schaffer, W. A. 2010. Regional impact models. Available from http://www.rri.wvu.edu/ WebBook/Schaffer (accessed 5 May 2010).

Snieska, V. \& Simkunaite, I. 2009. Socio-economic impact of infrastructure investments. Economics of Engineering Decisions (3), 16-25.

Trethaway, M. 2001. Economic impact of airports. Presentation to the CTC Conference.

Vickerman, R. 2007. Recent Evolution of Research into the Wider Economic Benefits of Transport Infrastructure Developments. Canterbury. Joint Transport Research Centre.

Washington State Department of Transport Aviation Division. 2001. WSDOT airport system plan update: Aviation system plan forecast and economic analysis study. Available from: http://www.wsdot.wa.gov/NR/rdonlyres/B44556D4-179C-48EF-80A5-EB27287172C5/0/ ImpactReport_1 to13.pdf (accessed 10 December 2009).

Willoughby, C. 2002. Infrastructure and pro-poor growth: Implications of recent research. Background paper prepared for Department for International Development, UK.

\section{Table of acronyms and abbreviations}

\begin{tabular}{|l|l|}
\hline ACI & Airports Council International \\
\hline ACSA & Airports Company South Africa Ltd \\
\hline AsgiSA & Accelerated and Shared Growth Initiative for South Africa \\
\hline ATAG & Air Transport Action Group \\
\hline CTIA & Cape Town International Airport \\
\hline DEAT & Department of Environmental Affairs and Tourism \\
\hline DIA & Durban International Airport \\
\hline DoT & Department of Transport \\
\hline GDP & gross domestic product \\
\hline I/O & input/output \\
\hline IDC & Industrial Development Corporation \\
\hline ORTIA & OR Tambo International Airport \\
\hline PAYE & Pay As You Earn \\
\hline SARS & South African Revenue Services \\
\hline SAT & South African Tourism \\
\hline Stats SA & Statistics South Africa \\
\hline VAT & Value Added Tax \\
\hline VFR & visiting friends and relatives \\
\hline
\end{tabular}

